\title{
Yield and physiological quality of wheat seeds after desiccation with different herbicides ${ }^{1}$
}

\author{
Fábio Henrique Krenchinski²*, Victor José Salomão $\mathrm{Cesco}^{2}$, Danilo Morilha \\ Rodrigues $^{2}$, Vinicius Gabriel Caneppele Pereira ${ }^{2}$, Alfredo Junior Paiola Albrecht ${ }^{3}$, \\ Leandro Paiola Albrecht ${ }^{3}$
}

\begin{abstract}
Some desiccation techniques for harvesting wheat may affect seed quality. The objective of this study was to evaluate the effect of different desiccant herbicides applied to the wheat crop and their effects on the production and seed quality. The experiment was conducted with cultivar COODETEC 150 (CD 150) in two sites in Palotina (Paraná state, Brazil) with a randomized block design consisting of 7 treatments (desiccation herbicides) and 4 replications. Desiccation was realized when $50 \%$ of the plants were in stage 80 with seeds in powdery or mass consistency. The variables analyzed were percentage of moisture content after harvest, Yield, hectoliter weight, mass of 100 seeds, vigor, germination, fresh mass of seedlings, dry mass of seedlings and root length. The herbicides carfentrazone-ethyl and clethodim were the ones that promoted greatest reduction in vigor. The herbicide paraquat caused reduction in seedling length. There was a reduction in the mass of 100 seeds for glufosinate-ammonium, clethodim, diquat and carfentrazone-ethyl. Glufosinate-ammonium, paraquat, glyphosate, clethodim and diquat caused reduction in yield. Desiccation of Cultivar CD 150 at stage 80 is not recommended, since plant Yield and physiological seed parameters were adversely affected by herbicides.
\end{abstract}

Index terms: chemical desiccation, management, germination, vigor, seedlings.

\section{Produtividade e qualidade fisiológica das sementes de trigo após dessecação com diferentes herbicidas}

\begin{abstract}
RESUMO - Algumas técnicas de manejo da cultura do trigo, como a dessecação pré-colheita podem afetar a produtividade e a qualidade fisiológica das sementes. O objetivo deste estudo foi avaliar o efeito de diferentes herbicidas dessecantes aplicados na cultura do trigo e seus efeitos sobre a produtividade e a qualidade das sementes. O experimento foi conduzido com a cultivar COODETEC 150 (CD 150), em dois ambientes de produção localizados no Município de Palotina - PR, sob o delineamento experimental de blocos casualisados, constituído de 7 tratamentos (herbicidas na dessecação) com 4 repetições. A dessecação foi realizada quando $50 \%$ das plantas apresentavam-se no estádio 80 com as sementes de consistência farinácea ou de massa. As variáveis analisadas foram umidade após a colheita, produtividade de sementes, peso hectolitro, massa de 100 sementes, germinação e vigor. Os herbicidas carfentrazoneethyl e clethodim reduziram o vigor das sementes produzidas, e o herbicida paraquat reduziu o comprimento de plântulas. Ocorreu redução na massa de 100 sementes para o amônio - glufosinate, clethodim, diquat e carfentrazone-ethyl. O amônio - glufosinate, paraquat, glyphosate, clethodim e diquat reduziram a produtividade. A dessecação de plantas da cultivar CD 150 no estádio 80 não é recomendada, em decorrências dos efeitos negativos dos herbicidas nos parâmetros produtivos e fisiológicos das sementes de trigo.
\end{abstract}

Termos para indexação: dessecação química, manejo, germinação, vigor, plântulas.

\section{Introduction}

Wheat (Triticum aestivum L.) is a plant from Southeast Asia, which formed the basis of the diet of ancient Persian,
Greek and Egyptian civilizations, thus having a major role in world nutrition (EMBRAPA, 2014). Nowadays, wheat occupies the second worldwide position in cereal production, 750 million tons; some of the major wheat producers are in

${ }^{3}$ Universidade Federal do Paraná, 85950-000 - Palotina, PR, Brasil. *Corresponding author $<$ fhkrenchinski@gmail.com>
${ }^{1}$ Submitted on 11/23/2016. Accepted for publication on 05/18/2017.

${ }^{2}$ Faculdade de Ciências Agronômicas - Unesp Botucatu, 18610-307 Botucatu, SP, Brasil. 
Asia, especially China, with 108 million tons, and India, with 75 million tons (FAO, 2016). Brazil produces 5,8 million tons of wheat (CONAB, 2016), with consumption of approximately 11,5 million tons (USDA, 2017). The major Brazilian producers are regions South, Southeast and CentralWest, especially Paraná (PR) state (in the South region) as the major wheat producer, with approximately 3,5 million tons, which is mostly due to weather conditions favorable to the cultivation of this cereal (Brasil, 2016).

The end product's final quality is related to handling during cultivation, including the practice of pre-crop desiccation; the moment chosen for application as well as the product applied may compromise productive parameters, and the physiological potential of seeds. According to Whigham and Stoller (1979), untimely desiccation, that is, before physiological maturation, may entail loss in Yield.

Physiological maturity occurs when there is a change in the relation between plant and seeds, that is, seeds stop receiving nutrients and photo-assimilated compounds, and this coincides with their moment of maximum physiological potential (Marcos-Filho, 2015). However, the point of physiological maturity is not necessarily the moment for cropping, since during this stage there is still a high degree of moisture content, approximately $40 \%$, which either poses problems or hinders harvesting (Carvalho and Nakagawa, 2012).

Wheat grains harvest must be done when seeds have reached $13 \%$ moisture content. However, this is not always possible, especially due to factors such as rains, and there occasionally may be need for earlier harvesting (EMBRAPA, 2014). One of the alternatives for harvest advancement and uniformity is chemical pre-harvest crop desiccation. Besides allowing for harvest advancement and planning, the use of desiccant herbicides guarantees higher efficiency during harvest, and higher control of weeds that may linger in the system (Marcos-Filho, 2015).

According to Lacerda et al. (2003), positive results are obtained with the use of desiccants, such as moisture content reduction and preservation of seed properties (a most important issue in wheat cultivation), since the rains of the next harvest season may drastically reduce the quantity of seeds. Some factors must be heeded when employing this preharvest practice, such as the mode of action of the herbicide to be used, environmental conditions at the moment of application, phenology and possible effects of desiccant use to end-product (Lacerda et al., 2005).

Factors such as the active principle of the herbicide, dosage and time of application must be very well set prior to desiccation, since the use of herbicides shortly before the period of physiological maturity of the plant may entail loss in Yield, and damage the quality of the seeds (Lacerda et al., 2005). This work's hypothesis is that some herbicides used in wheat desiccation affect its productive performance, as well as the seeds' physiological quality, which shows the need of recommendation for the use of these herbicides in the production of seeds, and even their commercialization.

The goal of the present study is thus to evaluate wheat desiccation with different herbicides, so as to assess their effects on Yield of seeds and on their physiological quality.

\section{Material and Methods}

Experiments were conducted at the second harvest 2013/14 (Winter, 2014), in field, at the Western region of Paraná (PR), in two locations. The first experiment was conducted in Palotina-PR (Site 1): S $24^{\circ} 20^{\prime} 01^{\prime}$, O $53^{\circ}$ 53'09", 337 meters height. The second experiment was also conducted in Palotina-PR, but in a different production site (Site 2): S $24^{\circ} 15^{\prime} 16^{\prime}$ ", O $53^{\circ} 55^{\prime} 43^{\prime \prime}, 341$ meters height. The region has Cfa climate (mesothermal humid subtropical) according to Köppen's classification.

The soil was classified as eutrudox Red Latosol, typical in both areas (EMBRAPA, 2013). A chemical and physical analysis of the soil was undertaken before the installation of the cultivation, in $0.00-0.20 \mathrm{~m}$, which yielded the following features: Site $1-\mathrm{pH}$ $\left(\mathrm{CaCl}_{2}\right)=5.6 ; \mathrm{Al}=0.0 \mathrm{cmol}_{\mathrm{c}} \cdot \mathrm{dm}^{-3}, \mathrm{H}+\mathrm{Al}=4.01 \mathrm{cmol}_{\mathrm{c}} \cdot \mathrm{dm}^{-3}, \mathrm{C}=$ 22.12 g.dm $\mathrm{dm}^{-3} ; \mathrm{P}($ Mehlich $)=5.22 \mathrm{mg} \cdot \mathrm{dm}^{-3} ; \mathrm{K}=0.66 \mathrm{cmol}_{\mathrm{c}} \cdot \mathrm{dm}^{-3}$; $\mathrm{Ca}=7.53 \mathrm{cmol}_{c^{\prime}} \cdot \mathrm{dm}^{-3} ; \mathrm{Mg}=3.68 \mathrm{cmol}_{\mathrm{c}} \cdot \mathrm{dm}^{-3} ; \mathrm{S}=6.53 \mathrm{mg} \cdot \mathrm{dm}^{-3}$; $\mathrm{CTC}=14.87 \mathrm{cmol}_{\mathrm{c}} \cdot \mathrm{dm}^{-3} \mathrm{e} \mathrm{V}=65.25 \%$. Lime, sand and silt total contents were, respectively, 66, 20 and 14\%. Site $2-\mathrm{pH}$ $\left(\mathrm{CaCl}_{2}\right)=5.5 ; \mathrm{Al}=0.0 \mathrm{cmol}_{\mathrm{c}} \mathrm{dm}^{-3}, \mathrm{H}+\mathrm{Al}=6.01 \mathrm{cmol}_{\mathrm{c}} \mathrm{dm}^{-3}, \mathrm{C}$ $=24.78 \mathrm{~g} \mathrm{dm}^{-3} ; \mathrm{P}($ Mehlich $)=6.41 \mathrm{mg} \mathrm{dm}^{-3} ; \mathrm{K}=0.81 \mathrm{cmol}_{\mathrm{c}}$ $\mathrm{dm}^{-3} ; \mathrm{Ca}=5.63 \mathrm{cmol} \mathrm{dm}_{\mathrm{c}}^{-3} ; \mathrm{Mg}=2.48 \mathrm{cmol}_{\mathrm{c}} \mathrm{dm}^{-3} ; \mathrm{S}=4.37$ mg. $\mathrm{dm}^{-3} ; \mathrm{CTC}=14.93 \mathrm{cmol}_{\mathrm{c}} \mathrm{dm}^{-3} \mathrm{e} \mathrm{V}=60 \%$. Lime, sand and silt total contents were, respectively, 67,23 and $10 \%$.

Rainfall data and average temperatures were collected daily, allowing the meteorological representation of both sites (Site 1 in Figure 1, and Site 2 in Figure 2).

For wheat cultivation, CD 150 was used, which presents high productive potential; it was sowed on May 15, 2014, with density of 300 seeds per $\mathrm{m}^{2}$, with fertilizing base of $309 \mathrm{~kg} \mathrm{ha}^{-1}$ and 10-15-15 NPK formulation. For weed control, metsulfuronmethyl was applied $\left(3 \mathrm{~g}\right.$ a.i. ha $\left.{ }^{-1}\right)+2,4-\mathrm{D}\left(1005 \mathrm{~g}\right.$ a.e.ha $\left.{ }^{-1}\right)$ in pre-tillering stage. Two insecticide applications were made; the first used lufenuron ( $5 \mathrm{~g}$ a.i. ha $\left.{ }^{-1}\right)$, and the second, methomyl (279 $\mathrm{g}$ a.i ha $\left.{ }^{-1}\right)$. Two applications with fungicides were made, the first with azoxystrobin + cyproconazole $\left(60+24 \mathrm{~g}\right.$ a.i. ha $\left.{ }^{-1}\right)$ at booting stage, and the second with pyraclostrobin + epoxiconazole (26,6 +10 g a.i. ha $\left.{ }^{-1}\right), 20$ days after the first application.

Randomized block design was applied, with four 
Site 1 Palotina-PR

May 15, 2014 - September 15, 2014

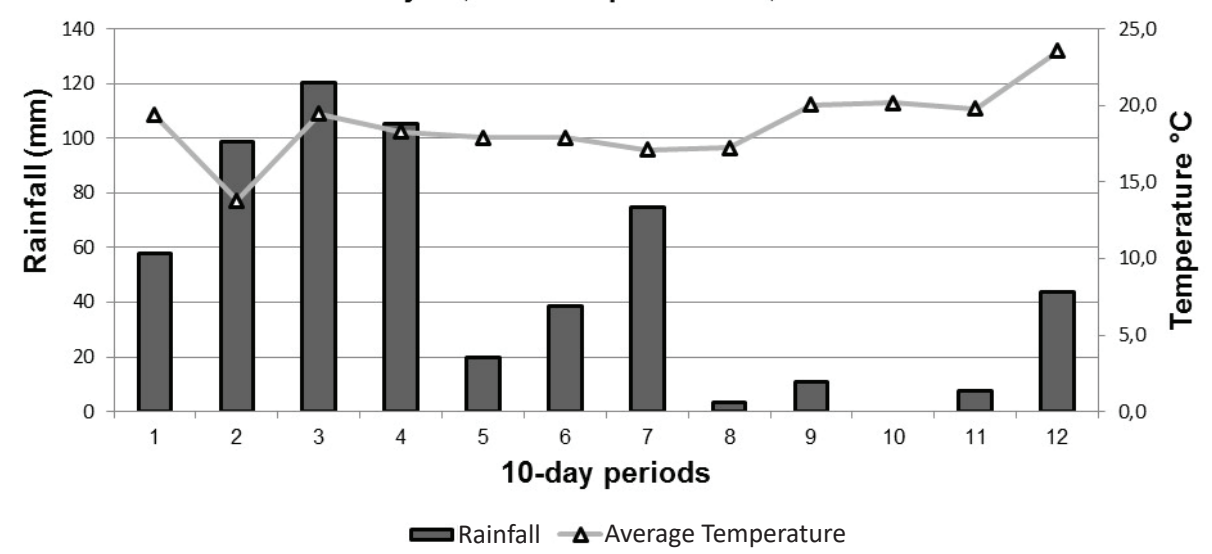

Figure 1. Rainfall and average temperatures during Winter 2014.

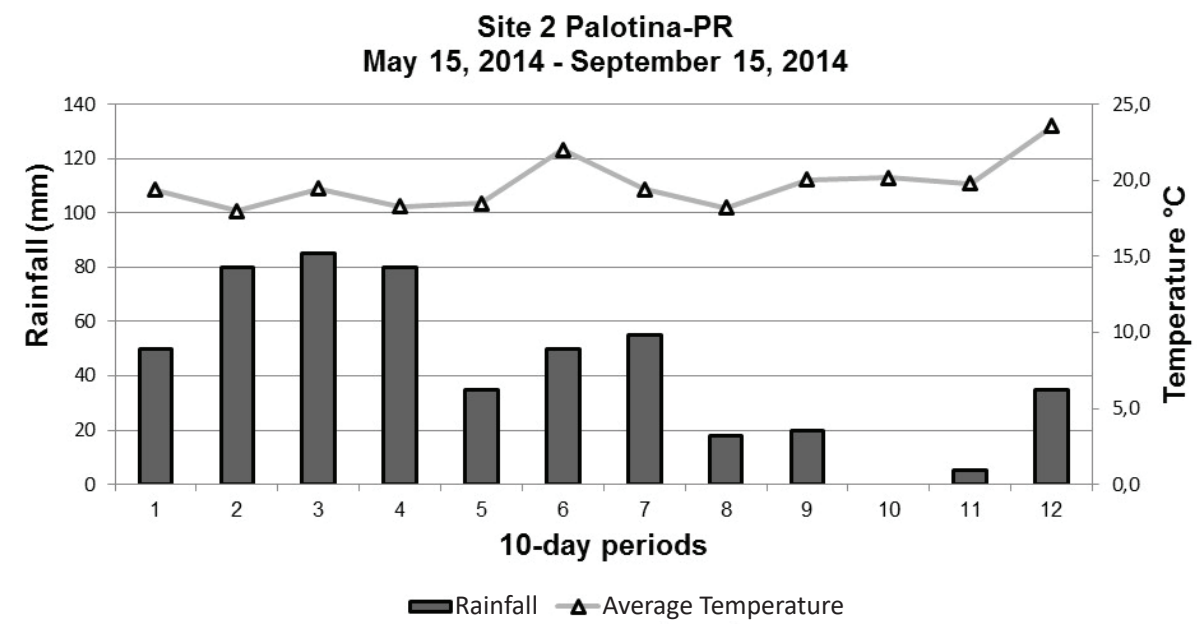

Figure 2. Rainfall and average temperatures during Winter 2014.

replications. Seven desiccation treatments were used: control group (no desiccant application), glufosinate-ammonium (500g a.i (active ingredient) ha $\mathrm{ha}^{-1}$, paraquat (400g a.i. ha-1), glyphosate (1200 g.a.e. (acid equivalent) ha ${ }^{-1}$ ), clethodim $\left(120 \mathrm{~g}\right.$ a.i. ha $\left.\mathrm{a}^{-1}\right)$, diquat (400g a.i. ha-1) and carfentrazone-ethyl $160 \mathrm{~g}$ a.i. $\left.\mathrm{ha}^{-1}\right)$; the action mechanisms of these herbicides were, respectively: glutamine synthetase inhibitor, photo-system 1 inhibitor, EPSPs inhibitors, ACCase inhibitors, photo-system 2 inhibitors, and PROTOX in inhibitors. Desiccation was realized when $50 \%$ of the plants were in stage 80 with seeds in powdery or mass consistency (Zadoks et al., 1974).

For herbicide application, a $\mathrm{CO}_{2}$ propelled sprayer backpack was used, with the following features: constant pressure (29 psi), flow 0.65 L.min. $^{-1}$, equipped with a wand containing six Teejet XR 110.02 spray tips, that, working at $50 \mathrm{~cm}$ high from target and with a speed of $1 \mathrm{~m} . \mathrm{s}^{-1}$, reached an extension of $50 \mathrm{~cm}$ width, providing spray volume of
200 L.ha-1 ${ }^{-1}$ Meteorological conditions at the moment of application were the following for Site 1: relative humidity: $63 \%$, wind speed: $1.2 \mathrm{~km} \cdot \mathrm{h}^{-1}$; temperature: $24^{\circ} \mathrm{C}$. They were the following for Site 2: relative humidity $66 \%$; wind speed $2.2 \mathrm{~km} . \mathrm{h}^{-1}$; temperature: $21^{\circ} \mathrm{C}$.

Experimental plots were made of 18 lines of 5 meters length ( $0.17 \mathrm{~m}$ spacing among lines). For the evaluations, an area of 6.8 $\mathrm{m}^{2}$, was used, of which only the 10 central lines were considered, disregarding $0.5 \mathrm{~m}$ in each extremity of the lines (borders).

Harvest was realized 15 days after desiccation treatments; all replications were maintained separate for the realization of seed-quality evaluation. The variables analyzed were: seed moisture content after harvest, Yield, hectoliter weight, mass of 100 seeds, vigor, first count of the germination test, fresh mass of seedlings, dry mass of seedlings and root length.

For the determination of Yield, the plot's useful area was harvested, the wheat cobs threshed in an experimental 
threshing machine, and the seeds weighted; after this, the seeds were sampled for the determination of moist content for each portion; at last, they were stored in paper bags. Yield was measured from harvest of the useful plot area, correcting moisture by $13 \%$ and converting it to $\mathrm{Kg} \mathrm{ha}^{-1}$. The mass of 100 seeds was obtained from counting eight samples with 100 seeds each; the results were expressed in grams. For the determination of moisture content and hectoliter weight, expressed in Kilogram per hectoliter $\left(\mathrm{Kg}_{\mathrm{hL}} \mathrm{hL}^{-1}\right)$, the method described in Brasil (2009) was followed.

Germination test was conducted with eight replications of 50 seeds, under temperature of $20^{\circ} \mathrm{C}$, using a roll-shaped paper towel substrate, moisturized with distilled water, in the ratio of 2.5 the mass of the dry paper. Evaluation of normal seedlings in the first count was done after 4 days; germination was evaluated eight days after seeding (Brasil, 2009).

For the evaluation of seedlings' dry mass and root length, the same procedures were followed as for germination, measurements being made in the date equivalent to the first count. 25 normal seedlings were weighted without the remnants of the reserve tissues; root length was measured, and then the seedlings were conditioned in paper bags and taken to the greenhouse, with forced air circulation at $65^{\circ} \mathrm{C}$ until constant weight was reached; only then was their dry mass weighted. The results were expressed in $\mathrm{cm}$ and grams per seedling.

The data were analyzed according to Pimentel-Gomes and Garcia (2002), and submitted to analysis of variance; when $F$ values were significant $(p<0.05)$, joint data analysis was conducted for both sites, with comparison of means by Tukey's test $(\mathrm{p}<0.05)$.

\section{Results and Discussion}

A significant difference was observed between both cultivation sites for moisture content of the seeds (Table 1), Site 1 seeds presented smaller moisture content than Site 2 seeds. Herbicides also influenced moisture content, especially ghyphosate, which resulted in the smallest moisture content in post-harvest seeds for both sites, differing from the other treatments (Table 1). Possibly, the smallest moisture content resulting from desiccation with glyphosate was related to its mode of action on the plant, inhibiting EPSP enzymes, which compromises the biosynthesis of vital amino acids, resulting in structural alterations and irreversible cell damage, such as partial rupture of the chloroplast, and rough endoplasmic reticulum water loss (Menezes et al., 2004).

Higher moisture content for both sites was obtained with the application of clethodim, with values very close to those found in non-desiccated samples. Carfentrazone also presented high moisture levels. The data verified with the application of carfentrazone corroborate Marchiori Jr. et al. (2002), who also observed that the utilization of this herbicide results in higher moisture of the seeds when compared to the other treatments and the control samples; the same was verified for paraquat used in canola (Albrecht et al., 2013).

According to Posner and Hibbs (1999), seed moisture defines the appropriate temperature and time for drying, and their conditioning for storage or industrial grinding processes, i.e. high moisture content in seeds implies higher amounts of time and energy in the drying phase, and, if this stage is not conducted properly, the remnant moisture may cause fermentation, which alters negatively the quality of wheat

Table 1. Cultivar CD 150 wheat seeds submitted to desiccation with different herbicides at stage 80: moisture content (\%), Yield (kg.ha-1) and hectoliter weight $\left(\mathrm{Kg}^{-1} \mathrm{hL}^{-1}\right)$.

\begin{tabular}{|c|c|c|c|c|c|c|}
\hline \multirow{2}{*}{ Treatments } & \multicolumn{2}{|c|}{ Moisture content } & \multicolumn{2}{|c|}{ Yield } & \multicolumn{2}{|c|}{ Hectoliter weight } \\
\hline & Site 1 & Site 2 & Site 1 & Site 2 & Site 1 & Site 2 \\
\hline Control group & $14.50 \mathrm{Ab}$ & $19.22 \mathrm{Ab}$ & $2894.48 \mathrm{Aa}$ & $2794.01 \mathrm{Aa}$ & $78.00 \mathrm{Aa}$ & $74.75 \mathrm{ABb}$ \\
\hline Glufosinate-ammonium & $12.37 \mathrm{ABb}$ & $17.35 \mathrm{BCa}$ & $2156.98 \mathrm{Ba}$ & $1915.71 \mathrm{Ca}$ & $78.75 \mathrm{Aa}$ & $77.00 \mathrm{ABa}$ \\
\hline Paraquat & $11.35 \mathrm{ABb}$ & $14.15 \mathrm{CDa}$ & $1992.44 \mathrm{Ba}$ & $1645.18 \mathrm{Ca}$ & $79.00 \mathrm{Aa}$ & $77.50 \mathrm{ABa}$ \\
\hline Glyphosate & $10.47 \mathrm{Bb}$ & $13.67 \mathrm{Da}$ & $1973.79 \mathrm{Ba}$ & $1724.98 \mathrm{Ca}$ & $81.25 \mathrm{Aa}$ & $78.50 \mathrm{Aa}$ \\
\hline Clethodim & $14.50 \mathrm{Ab}$ & $21.42 \mathrm{Aa}$ & $2165.81 \mathrm{Ba}$ & $2490.19 \mathrm{ABa}$ & $77.50 \mathrm{Aa}$ & $73.75 \mathrm{ABb}$ \\
\hline Diquat & $13.02 \mathrm{ABb}$ & $18.97 \mathrm{ABa}$ & $2063.86 \mathrm{Ba}$ & $2112.32 \mathrm{BCa}$ & $79.75 \mathrm{Aa}$ & $76.00 \mathrm{ABb}$ \\
\hline Carfentrazone-ethyl & $14.10 \mathrm{Ab}$ & $20.85 \mathrm{Aa}$ & $2412.66 \mathrm{ABa}$ & $2709.09 \mathrm{Aa}$ & $80.00 \mathrm{Aa}$ & $73.25 \mathrm{Bb}$ \\
\hline $\begin{array}{l}\text { Significant Average } \\
\text { Deviation (treatment) }\end{array}$ & \multicolumn{2}{|c|}{3.35} & \multicolumn{2}{|c|}{570.40} & \multicolumn{2}{|c|}{5.17} \\
\hline $\begin{array}{l}\text { Significant Average } \\
\text { Deviation (site) }\end{array}$ & \multicolumn{2}{|c|}{2.18} & \multicolumn{2}{|c|}{371.22} & \multicolumn{2}{|c|}{3.36} \\
\hline $\mathrm{CV} \%$ & \multicolumn{2}{|c|}{9.88} & \multicolumn{2}{|c|}{11.70} & \multicolumn{2}{|c|}{3.04} \\
\hline
\end{tabular}

Equal capital letters in the columns among treatments and equal regular letters between sites do not differ by Tukey's test ( $\mathrm{p}<0.05)$. 
(Carneiro et al., 2005), besides leading to the growth of plagues and fungi, damaging seeds (Koch et al., 2006).

Sites exerted no influence over the Yield of wheat seeds (Table 1); however, it was observed that desiccation influenced negatively the Yield of the seeds, considering that, for both sites, control samples presented higher Yield in relation to some treatments.

Herbicides carfentrazone-ethyl (Sites 1 and 2) and clethodim (Site 2) bore statistically identical results when compared to the control sample. In Site 1, there was a reduction of Yield by 25.5, 31, 32, 25 and 29\% for herbicides glufosinate-ammonium, paraquat, glyphosate, clethodim and diquat, respectively. In Site 2, there was a reduction of Yield by $31.5,41,38$ e $24 \%$ for herbicides glufosinate-ammonium, paraquat, glyphosate and diquat, respectively (Table 1). The feature observed in some herbicides which may have lead to a reduction in seed Yield in both sites may have been their quick inhibition of photosynthesis, which may have compromised the transportation of photo-assimilated compounds to the seeds, thus affecting their Yield (Pereira et al., 2015), as desiccation was realized near the period of physiological maturity, but this does not guarantee that all seeds of all plants had detached from their mother-plants, as wheat maturation is not uniform.

Desiccation did not alter hectoliter $(\mathrm{PH})$ weight of seeds in Site 1; in Site 2, carfentrazone-ethyl occasioned PH reduction in relation to glyphosate (Table 1). In Site 2, glyphosate was the treatment that yielded higher PH, differing from the other treatments. Samples treated with clethodim, diquat, carfentrazone-ethyl and the control sample presented lower $\mathrm{PH}$ in Site 2, when compared to Site 1. According to FleuratLessard (2002), PH reduction may be attributed to metabolic processes in the seeds, and to organisms associated with these processes, provoking the consumption of nutritive reserves. $\mathrm{PH}$ reduction in wheat seeds was caused by carfentrazoneethyl due to its mode of action, degrading lipids and proteins on the surfaces it affects (Werlang and Silva, 2002), so it may have impacted wheat seeds right after application, due to the reduction in lipids and proteins, and the appearance of malformed grains; according to Battisti et al., (2011), these are the factors that have higher impact on the PH of wheat seeds.

Contrary to what the present study attests, Bellé et al., (2014), when evaluating desiccants glyphosate and paraquat, found no significant difference in Yield for cultivar Quartzo wheat; the same result was shown by Santos and Vicente (2009), demonstrating variations in cultivation behavior due to genotype alteration and production environment.

According to Mellado and Pedreros (2005), desiccation at stages 77 and 83 with glyphosate and paraquat diminish
Yield and hectoliter weight in relation to the control sample, in which these products are not applied; this is similar to what was observed in the present study, but Mellado and Pedreros note that, when the application is done at stage 87 , no damage is observable in these features.

According to Yenish and Young (2000), diminution in Yield and PH by desiccant application at stages 77 and 83 is due to the seeds not being physiologically matured, thus inhibiting the transportation of photo-assimilated compounds to the seeds, which may be one of the explanations for the effects found in the present study.

The 100-seed mass (Table 2) of wheat was affected by the application of desiccants in both sites. The control group and the groups applied ghyphosate and paraquat presented higher 100 -seed mass in both sites; on the other hand, glufosinateammonium, clethodim, diquat and carfentrazone-ethyl caused a diminution in 100-seed mass. The difference in 100-seed mass among the herbicides applied may be explained by different stress levels caused on wheat plants. Glufosinateammonium, clethodim, diquat and carfentrazone-ethyl may have caused higher stress levels on the plants; the transportation of photo-assimilated compounds to the seed (draining) may therefore have diminished, entailing a smaller 100 -seed mass in relation to the other treatments and the control group. The 100-seed mass was higher for Site 1 than for Site 2 for all treatments, which reveals that the production environment interferes in wheat plants, which will present the same tendency for desiccation treatments.

Clethodim drastically diminished the percentage of normal wheat seedling in the first count of the germination test in both sites (Table 2), being below the control group (no application) by $23 \%$ in Site 1 and $35.75 \%$ in Site 2 . Carfentrazone-ethyl and diquat also reduced the vigor of wheat seeds. Glufosinate-ammonium and glyphosate had performances equal to the control group in both Sites. As for desiccated wheat seeds germination percentage (Table 2), it is evident that herbicides that had diminished the vigor did not influence final germination, because no difference was observable between germination of the treated groups and that of the control group. These data partially corroborate those of Santos and Vicente (2009), who observed in their study that the pre-harvest utilization of herbicides reduced neither germination nor Yield of the seeds.

Site 1 desiccation with cultivar CD 150 did not alter wheat seedlings dry mass parameters (Table 3 ). According to Tillmann and West (2004), higher seed mass guarantees better seedling development, due to the higher accumulation of seed reserves. Wheat seedling dry mass (Table 3) was negatively influenced by glufosinate-ammonium in Site 2 . 
Table 2. Cultivar CD 150 wheat seeds submitted to desiccation with different herbicides at stage 80: 100-seed mass (g), normal seedlings in the first count of the germination test (\%) and total germination (\%).

\begin{tabular}{|c|c|c|c|c|c|c|}
\hline \multirow{2}{*}{ Treatments } & \multicolumn{2}{|c|}{100 -seed mass } & \multicolumn{2}{|c|}{ First count } & \multicolumn{2}{|c|}{ Total germination } \\
\hline & Site 1 & Site 2 & Site 1 & Site 2 & Site 1 & Site 2 \\
\hline Control group & $3.60 \mathrm{ABa}$ & $2.44 \mathrm{ABb}$ & $77.25 \mathrm{Aa}$ & $86.25 \mathrm{Aa}$ & $89.00 \mathrm{Aa}$ & $85.00 \mathrm{Aa}$ \\
\hline Glufosinate-ammonium. & $3.25 \mathrm{BCa}$ & $2.20 \mathrm{BCb}$ & $75.75 \mathrm{Aa}$ & $84.00 \mathrm{Aa}$ & $89.00 \mathrm{Aa}$ & $93.00 \mathrm{Aa}$ \\
\hline Paraquat & $3.57 \mathrm{ABa}$ & $2.67 \mathrm{ABb}$ & $69.25 \mathrm{Aa}$ & $74.50 \mathrm{ABa}$ & $90.00 \mathrm{Aa}$ & $83.00 \mathrm{Aa}$ \\
\hline Glyphosate & $4.01 \mathrm{Aa}$ & $2.91 \mathrm{Ab}$ & $73.15 \mathrm{Aa}$ & $80.00 \mathrm{Aa}$ & $89.00 \mathrm{Aa}$ & $84.00 \mathrm{Aa}$ \\
\hline Clethodim & $3.04 \mathrm{BCa}$ & $2.12 \mathrm{Cb}$ & $54.25 \mathrm{Ba}$ & $50.50 \mathrm{Ca}$ & $90.00 \mathrm{Aa}$ & $83.00 \mathrm{Aa}$ \\
\hline Diquat & $3.35 \mathrm{BCa}$ & $2.16 \mathrm{BCb}$ & $65.00 \mathrm{Aa}$ & $68.75 \mathrm{Ba}$ & $93.00 \mathrm{Aa}$ & $94.00 \mathrm{Aa}$ \\
\hline Carfentrazone-ethyl & $2.98 \mathrm{Ca}$ & $2.15 \mathrm{BCb}$ & $62.25 \mathrm{ABa}$ & $60.25 \mathrm{BCa}$ & $90.00 \mathrm{Aa}$ & $83.50 \mathrm{Aa}$ \\
\hline $\begin{array}{c}\text { Significant Average } \\
\text { Deviation (treatment) }\end{array}$ & \multicolumn{2}{|c|}{0.54} & \multicolumn{2}{|c|}{10.75} & \multicolumn{2}{|c|}{16.93} \\
\hline $\begin{array}{c}\text { Significant Average } \\
\text { Deviation (site) }\end{array}$ & \multicolumn{2}{|c|}{0.35} & \multicolumn{2}{|c|}{8.99} & \multicolumn{2}{|c|}{11.02} \\
\hline $\mathrm{CV} \%$ & \multicolumn{2}{|c|}{8.59} & \multicolumn{2}{|c|}{7.10} & \multicolumn{2}{|c|}{8.72} \\
\hline
\end{tabular}

Equal capital letters in the columns among treatments and equal regular letters between sites do not differ by Tukey's test ( $<<0.05)$.

Table 3. Cultivar CD 150 wheat seeds submitted to desiccation with different herbicides at stage 80 : seedling dry mass (g) and seedling length $(\mathrm{cm})$.

\begin{tabular}{|c|c|c|c|c|}
\hline \multirow{2}{*}{ Treatments } & \multicolumn{2}{|c|}{ Seedling dry mass } & \multicolumn{2}{|c|}{ Seedling length } \\
\hline & Site 1 & Site 2 & Site 1 & Site 2 \\
\hline Control group & $0.31 \mathrm{Aa}$ & $0.31 \mathrm{Aa}$ & $9.52 \mathrm{Aa}$ & $8.50 \mathrm{Aa}$ \\
\hline Glufosinate-ammonium. & $0.30 \mathrm{Aa}$ & $0.27 \mathrm{Ba}$ & $9.52 \mathrm{Aa}$ & $7.60 \mathrm{Bb}$ \\
\hline Paraquat & $0.30 \mathrm{Aa}$ & $0.28 \mathrm{ABa}$ & $7.32 \mathrm{Ba}$ & $4.85 \mathrm{Cb}$ \\
\hline Glyphosate & $0.31 \mathrm{Aa}$ & $0.29 \mathrm{ABa}$ & $8.14 \mathrm{ABa}$ & $7.06 \mathrm{ABa}$ \\
\hline Clethodim & $0.32 \mathrm{Aa}$ & $0.31 \mathrm{ABa}$ & $8.85 \mathrm{ABa}$ & $6.52 \mathrm{BCb}$ \\
\hline Diquat & $0.30 \mathrm{Aa}$ & $0.30 \mathrm{ABa}$ & $8.64 \mathrm{ABa}$ & $7.44 \mathrm{ABa}$ \\
\hline Carfentrazone-ethyl & $0.33 \mathrm{Aa}$ & $0.30 \mathrm{ABb}$ & $7.33 \mathrm{ABa}$ & $7.31 \mathrm{ABa}$ \\
\hline Significant Average Deviation (treatment) & \multicolumn{2}{|c|}{0.04} & \multicolumn{2}{|c|}{1.85} \\
\hline Significant Average Deviation (site) & \multicolumn{2}{|c|}{0.02} & \multicolumn{2}{|c|}{1.20} \\
\hline $\mathrm{CV} \%$ & \multicolumn{2}{|c|}{6.31} & \multicolumn{2}{|c|}{10.80} \\
\hline
\end{tabular}

Equal capital letters in the columns among treatments and equal regular letters between sites do not differ by Tukey's test ( $<<0.05)$.

Cultivar CD 150 seedlings submitted to pre-harvest desiccation presented a difference as to seedling length (Table 3); use of paraquat, in both sites, resulted in the smallest seedling length, differing significantly from control group. Glufosinate-ammonium, paraquat and clethodim had superior performance in Site 1, in relation to Site 2.

Seed vigor influences development features of the future plants. Soy plants stemming from high-vigor seeds were higher, had larger diameter and higher leaf energy absorption capacity (Scheeren et al., 2010; Almeida and Mundstock, 2001); moreover, they influence cultivation Yield (Schuch et al., 2009). Mellado and Pedreiros (2005), applying desiccants 2,4-D, glyphosate, glyphosate + MCPA and paraquat at stages 77,83 and 87 also found negative impacts on seed germination of the desiccated seeds, when compared to the control group.

The results observed demonstrate that, when the different herbicides were applied, there was damage to wheat cultivation for both Yield, physiological quality of the seeds and seedling development. This evidences the difficulties in desiccation management for this type of cultivation, and explicits the need for specific studies that would enable appropriate decisionmaking pertaining pre-harvest desiccation, which must be employed in some situations.

\section{Conclusions}

Yield, 100-seed mass and hectoliter weight are reduced by plant desiccation with different herbicides.

Wheat seed germination is not altered by the application of desiccants at stage 80 , but there is reduction in the vigor of the seeds.

Desiccation of cultivar CD 150 plants at stage 80 is not 
recommended, due to the negative effects on the productive and physiological parameters of the wheat seeds.

\section{References}

ALBRECHT, L.; KRENCHINSKI, F.; PLACIDO, H.; BOMM, M.; KUNZ, V.; KORBER, A.; BIELER, R. Dessecação de canola em diferentes pontos de maturação das síliquas. Revista Brasileira de Herbicidas, v.12, n.2, p.143-150, 2013. http://www.rbherbicidas. com.br/index.php/rbh/article/view/188/197

ALMEIDA, M.L.; MUNDSTOCK, C.M. O afilhamento da aveia afetado pela qualidade da luz em plantas sob condições de competição. Ciência Rural, v.31, n.3, p.393-400, 2001. http://www.scielo.br/ scielo.php?script=sci_arttext\&pid $=\mathrm{S} 0103-84782001000300005$

BATTISTI, R.; SOMAVILLA, L.; BUSANELLO, C.; SCHWERZ, L. Eficiência do uso da massa hectolitro como teste rápido de vigor de semente de trigo (Triticum aestivum). Revista da Faculdade de Zootecnia, Veterinária e Agronomia, v.18, n.1, p.1-11, 2011. http:// revistaseletronicas.pucrs.br/ojs/index.php/fzva/article/view/8605/0

BELLÉ, C.; KULCZYNSKI, S.M.; BASSO, C.J.; KASPARY, T.E.; LAMEGO, F.P.; BISON, M. Produtividade e qualidade de sementes de trigo em função de estádios de dessecação e herbicidas. Journal of Seed Science, v.36, n.1, p.63-70, 2014. http://submission.scielo.br/ index.php/jss/article/view/123340

BRASIL. Ministério da Agricultura, Pecuária e Abastecimento. Regras para análise de sementes. Ministério da Agricultura, Pecuária e Abastecimento. Secretaria de Defesa Agropecuária. Brasília, DF: MAPA/ACS, 2009. 395p. http://www.agricultura.gov.br/arq_editor/ file/2946_regras_analise_sementes.pdf.

BRASIL. Ministério da Agricultura, Pecuária e Abastecimento. Secretaria de Defesa Agropecuária. Trigo. Brasília: MAPA. 2016. http://www.agricultura.gov.br/vegetal/culturas/trigo.

CARNEIRO, L.M.T.A.; BIAGI, J.D.; FREITAS, J.G.; CARNEIRO, M.C.; FELICIO, J.C. Diferentes épocas de colheita, secagem e armazenamento na qualidade de grãos de trigo comum e duro. Bragantia, v.64, n.1, p.127-137, 2005. http://www.scielo.br/pdf/ brag/v64n1/23860.pdf

CARVALHO, N.M.; NAKAGAWA, J. Sementes: ciência, tecnologia e produção, 5.ed. Jaboticabal: FUNEP, 2012. 590 p.

CONAB - Companhia Nacional de Abastecimento. Acompanhamento da Safra Brasileira de Grãos. v.3, n.8. Oitavo levantamento. Maio 2016. http:/www.conab.gov.br/OlalaCMS/uploads/ arquivos/16_05_27_09_24_04_boletim_graos_maio_2016_final.pdf. Accessed on: May. $\overline{2} 9^{\text {th }}, 2016$.

EMBRAPA. Empresa Brasileira de Pesquisa Agropecuária. Sistema de classificação dos solos. Embrapa solos, 3ed. Rio de Janeiro, 2013. $353 \mathrm{p}$.

EMBRAPA. Empresa Brasileira de Pesquisa Agropecuária. Informações Técnicas para Trigo e Triticale. 2014. https://www. embrapa.br/documents/1355291/1729833/2015inf + tecn + trigo $+\% 20$ e+triticale.pdf/205d3919-c572-4410-bc4d-1499b94333ba.
FAO. Statistical Databases. http://faostat.fao.org. Accessed on: May. $29^{\text {th }}, 2016$.

FLEURAT-LESSARD, F. Qualitative reasoning and integrated management of the quality of stored grain: a promising new approach. Journal of Stored Products Research, v.38, p.191-218, 2002. http:// www.sciencedirect.com/science/article/pii/S0022474X01000224

KOCH, H.J.; PRINGASM, C.; MAERLAENDER, B. Evaluation of environmental and management effects on Fusarium head blight infection and deoxynivalenol concentration in the grain of winter wheat. European Journal of Agronomy, v.24, n.2, p.357-366, 2006. http:// www.sciencedirect.com/science/article/pii/S1161030106000153

LACERDA, A.L.S.; LAZARINI, E.; SÁ, M.E.; VALÉRIO FILHO, W.V. Armazenamento de sementes de soja dessecadas e avaliação da qualidade fisiológica, bioquímica e sanitária. Revista Brasileira de Sementes, v.25, n.2, p.97-105, 2003. http:/www.scielo.br/pdf/rbs/ v25n2/19655.pdf

LACERDA, A.L.S.; LAZARINI, E.; SÁ, M.E.; VALÉRIO FILHO, W.V. Efeitos da dessecação de plantas de soja no potencial fisiológico e sanitário das sementes. Bragantia, v.64, n.3, p.447-457, 2005. http://www.scielo.br/scielo.php?script=sci arttext\&pid=S0006-87052005000300015

MARCHIORI JR, O.; INOUE, M.H.; BRACCINI, A.L.; OLIVEIRA JR, R.S.; AVILA, M.R. Qualidade e produtividade de sementes de canola(Brassica napus)apósaplicaçãodedessecantesempré-colheita. Planta Daninha, v.20, n.2, p.253-262, 2002. http://www.scielo.br/ scielo.php?script=sci_arttext\&pid=S0100-83582002000200012

MARCOS-FILHO, J. Fisiologia de sementes de plantas cultivadas. Piracicaba: FEALQ, 2015. 659p.

MELlADO, M. Z.; PEDREROS, A. L. Efecto de herbicidas aplicados durante la madurez del grano de trigo em el rendimiento y calidad del grano. Agricultura Técnica, v.65, n.3, p.312- 318, 2005. http://www.scielo.cl/scielo.php?script=sci arttext\&pid=S0365-28072005000300009

MENEZES, S. M.; TILlmanN, M. A. A.; Villela, F. A. Detecção de soja geneticamente modificada tolerante ao glifosato por métodos baseados na atividade de enzimas. Revista Brasileira de Sementes, v.26, n.2, p.150-155, 2004. http://www.scielo.br/pdf/ $\mathrm{rbs} / \mathrm{v} 26 \mathrm{n} 2 / 24502 . \mathrm{pdf}$

PEREIRA, T.; COELHO, C.M.M.; SOUZA, C.A.; MANTOVANI, A.; MATHIAS, V. Dessecação química para antecipação de colheita em cultivares de soja. Semina, v.36, n.4, p.2383-2394, 2015. http://www.uel.br/revistas/uel/index.php/semagrarias/article/ viewFile/16028/16779

PIMENTEL-GOMES, F.; GARCIA, C.H. Estatística aplicada a experimentos agronômicos e florestais: exposição com exemplos e orientações para uso de aplicativos. Piracicaba: FEALQ, 309p. 2002.

POSNER, E.S.; HIBBS, A.N. Wheat flour milling. 2ed. Minnesota: American Association of Cereal Chemists, 1999. 341p.

SANTOS, P.R.R.; VICENTE, D. Momento fisiológico das plantas de trigo para a dessecação e seus efeitos no rendimento de grãos. Cultivando o Saber, v.2, n.2, p.52-62, 2009. http://www.fag.edu.br/ graduacao/agronomia/\%20csvolume22/06.pdf 
SCHEEREN, B.R.; PESKE, S.T.; SCHUCH, L.O.B.; BARROS, A.C.A. Qualidade fisiológica e produtividade de sementes de soja. Revista Brasileira de Sementes, v. 32, n.3, p.35-41, 2010. http:// www.scielo.br/pdf/rbs/v32n3/v32n3a04.pdf

SCHUCH, L.O.B.; KOLCHINSKI, E. M.; FINATTO, J.A. Qualidade fisiológica da semente e desempenho de plantas isoladas em soja. Revista Brasileira de Sementes, v.31, n.1, p.144-149, 2009. http:/www.scielo.br/ scielo.php?script=sci_arttext\&pid=S010131222009000100016

TILLMANN, M.A.A.; WEST, S.H. Identification of genetically modified soybean seeds resistant to glyphosate. Scientia Agricola, v.61, n.3, p.336-341, 2004. http://www.scielo.br/scielo. php?script=sci_arttext\&pid=S0103-90162004000300017

USDA. Foreign Agricultural Service. Grain and Feed - Brazil. 2017. https://gain.fas.usda.gov/Recent\%20GAIN\%20Publications/ Grain\%20and\%20Feed\%20Update_Brasilia_Brazil_2-2-2017.pdf. Accessed on: Apr. 17 $7^{\text {th }}, 2017$.

WERLANG, R.C.; SILVA, A.A. Interação de glyphosate com carfentrazone-ethyl. Planta Daninha, v.20, n.1, p.93102, 2002. http://www.scielo.br/scielo.php?script $=$ sci arttext\&pid=S010083582002000100013\&lng=en\&nrm=iso
WHIGHAM, D.K.; STOLLER, E.W. Soybean desiccation by paraquat, glyphosate and ametryn to accelerate harvest. Agronomy Journal, v.71, n.3, p.630-633, 1979. https://dl.sciencesocieties.org/ publications/aj/abstracts/71/4/AJ0710040630 access $=0 \&$ view $=$ pdf

YENISH, J.P.; YOUNG, F.L. Effect of pre harvest glyphosate application on seed and seeding quality of spring wheat (Triticum aestivum L.). Weed Technology, v.14, n.1, p.212 - 217, 2000. http://www.bioone.org/doi/10.1614/0890037X$\% 282000 \% 29014 \% 5$ B $0212 \% 3$ AEOPGAO \%5D2.0.CO\%3B2

ZADOKS, J.C.; CHANG, T.T.; KONZAK, B.F. A decimal code for the growth stages of cereals. Weed Research, v.14, n.6, p.415-421, 1974. http://onlinelibrary.wiley.com/doi/10.1111/j.1365-3180.1974. tb01084.x/full 